\title{
APPLYING TIME DRIVEN ACTIVITY-BASED COSTING TO CALCULATE COST OF COMPUTED TOMOGRAPHY SCAN IN A TEACHING HOSPITAL
}

\author{
C. Narender Kumar ${ }^{1}$
}

${ }^{1}$ Assistant Professor, Department of Hospital Administration, Government Medical College Hospital, Nizamabad, Telangana.

\section{ABSTRACT}

\section{BACKGROUND}

Escalating healthcare cost is a challenge in public health sector for financial manager. Choosing an appropriate accounting method is necessary for cost containment. In present study, we applied the time driven activity-based costing method to assess the cost in performing a computed tomography in a teaching hospital.

The objectives of this study are: 1) To describe the application of Time Driven Activity-Based Costing (TDABC) to Computed Tomography (CT) scanning unit; 2) To obtain the cost of unused capacity of personnel and idle time cost of CT scanner; and 3) To appraise the evidence of benefits of such tools in health sector and its efficiency.

\section{MATERIALS AND METHODS}

The prospective and cross-sectional study was conducted to obtain data. We utilised the process mapping, time motion study and activity-based costing. The labour cost, machine hour cost, material cost and overhead cost were estimated. Capacity cost rate was calculated. The final costs of each type of CT procedure were obtained by summing up each cost components. Unused capacity cost and idle time cost were calculated.

\section{RESULTS}

The component costs of a CT scan study were as follows: The machine hour cost (42.87\%) comprises of the highest share for the CT brain and other costs are in descending order, direct labour cost (20.73\%), direct material cost (14.69\%), batch level cost (13.01\%), facility level cost (4.81\%) and sustaining level cost (3.89\%). For CT brain contrast the direct material cost (41.13\%) comprises of the highest share and other costs are in descending order, machine hour cost (28.15\%), direct labour cost (15.44\%), batch level cost (9.56\%), facility level cost (3.16\%) and sustaining level cost (2.56\%). The unused capacity or idle time cost of the radiologist was Rs. 64812.80 and resident doctor's cost was Rs. 31684.80. The idle time cost of CT scanner was Rs. 50,05,560.

\section{CONCLUSION}

Time-driven activity-based costing allows detailed understanding of costs of all resources and precision of cost rate per minute. It provides valuable insights into process variability, resource utilisation, unused capacity and idle time cost. It provides potential opportunities for cost containment and efficiency in the utilisation of CT service.

\section{KEYWORDS}

Time-Driven Activity-Based Costing, CT Scanner, Public Hospital.

HOW TO CITE THIS ARTICLE: Kumar CN. Applying time driven activity-based costing to calculate cost of computed tomography scan in a teaching hospital. J. Evolution Med. Dent. Sci. 2017;6(52):3979-3987, DOI: 10.14260/Jemds/2017/861

\section{BACKGROUND}

The radiology equipment shares $40-60 \%$ of all medical equipments. The CT imaging attracts the attention in terms of the clear images and its cost and revenue.[1]

Costing assigns monetary values to those resources involved in the operations. ${ }^{[2]}$ Conventional costing method utilizes a single, volume-based cost driver, allocates the overhead costs to products on the basis of their relative usage which gives an incorrect relationship between products and costs. ${ }^{[3]}$

Healthcare system always faces pressures to deliver efficient care in the escalating demand and costs. Many

Financial or Other, Competing Interest: None.

Submission 24-05-2017, Peer Review 16-05-2017,

Acceptance 23-05-2017, Published 29-06-2017.

Corresponding Author:

Dr. C. Narender Kumar

Assistant Professor,

Department of Hospital Administration,

Government Medical College Hospital,

Nizamabad, Telangana State, India.

E-mail: cnarender24@gmail.com

DOI: $10.14260 /$ jemds $/ 2017 / 861$

managers searched for new tools like Activity-Based Costing (ABC) to rationalize the usage of resources. It deals with activity analysis, charges, diversity, complexity and specific characteristics of each activity. ${ }^{[4]}$ During the 1980s in the USA, as a result of a study by Professor Robert S. Kaplan of Harvard Business School and his junior colleague Robin Cooper, a British accountant from the Claremont Graduate School this method was conceived to correct the misleading overhead allocation. [5]

In this method, the project is subdivided into discrete, quantifiable activity or a work unit. An activity is an event, task or unit of work or process with a specified purpose; it requires time and associated resources. The productivity of the activity can be measured in units (e.g. number of samples versus man hours), and a cost estimate is prepared for each activity. These individual cost estimates will contain all labour, material, equipment and subcontracting costs including overheads for each activity. All individual estimates summed to obtain overall estimates.[6,7] Many health care managers who have tried to implement $A B C$ in their organisations have encountered many problems and the model was not accurate or granular enough to capture the complexity of multiple activities. 
It is too costly to process, store and update. To solve these problems, Kaplan and Anderson (2004, 2007) developed time-driven activity-based costing (TDABC) to simplify the calculations needed to generate product costs and estimates require only two parameters, the unit cost activity and the time required to perform a transaction or an activity.[8-12]

This model is suitable for service organisation such as a hospital. It identifies the unused capacity or idle time cost in activities, thus it creates scope for the efficient use of resources. It identifies opportunities for improvement of services in a hospital.[13-15]

CT scanning is one of the most common diagnostic procedures performed in hospitals and it is an important cost centre. The objectives of this study are-

1. To describe the application of TDABC method in CT scanning unit of the hospital.

2. To obtain the cost of unused capacity of personnel and idle time cost of CT scanner.

3. To appraise the evidence of benefits of such tools in health sector and its efficiency.

\section{MATERIALS AND METHODS}

The study is an observational, empirical, descriptive and cross-sectional. The study was conducted over a period of 6 months in a teaching hospital. We used three management tools- process mapping, time motion study and activity-based costing (time-derived). The ethical clearance for the study is obtained from the Institutional Ethics Committee. Based on the previous studies, we applied TDABC method to calculate CT scan costs.[16-20]

\section{Development of Process Maps}

The process map for CT scanning was prepared; details of each step were noted; its activity, duration, personnel and equipment that involved in its cycle, Figure 1.

\section{Obtain Time Estimates}

Time motion study was conducted for brain and abdomen CT procedures to estimate the time for each activity and the mean time was calculated. The cumulative time of all activities for each procedure is calculated.

\section{Estimate the Costs of Resources \\ The Cost of Person's Activity per Minute}

The costs of all personnel obtained from HR Department. The practical time of activity of each person was 138 days in half year and they worked for 6 hours (828). The working time in a shift was 8 hours. The working days were calculated by subtracting holidays and all leaves. The minute rate was calculated by dividing the six months gross salary by 49,680 minutes.

\section{Equipment Cost}

The depreciation (Toshiba single slice 2008) estimated by the straight line diminished balance method and the depreciation cost for half year and per minute calculated. The energy consumed by CT scanner was $52 \mathrm{KWH}$ and the cost was calculated per minute. To calculate the machine hour rate, the notional rental cost of CT unit area was taken from the Engineering Department and local market rates and the annual maintenance cost of machine was calculated per minute.

\section{Material Cost}

The details are obtained from store's records. The lab test cost was obtained from laboratory.

\section{Overhead Costs}

It includes the costs of building maintenance, the auxiliary equipment depreciation and furniture depreciation, energy consumed by air conditioning, computers, printers, fans, lights, indirect consumables, housekeeping, linen consumed, laundry expenses, information technology, property tax for CT scan unit area and the expenses of administration, managerial and stores functionaries (Apportioned). Cost per minute of overheads are estimated.

\section{Estimate the CCR}

CCR is defined as the cost of resource per unit time (Rupees per minute). To calculate this, the half year total capacity and the practical capacity in minutes were estimated for each resource. The Half Year Practical Capacity (HYPC) of personnel was estimated on the basis of the working days. The HYPC of equipment was number of days excluding the maintenance and breakdown days. For each resource, the half year cost was then divided by the practical capacity (used) in minutes to determine the CCR.

\section{Calculate the Final Cost of a CT Scan}

The duration of time for each activity was multiplied by CCR for all involved resources to calculate the cost. The total cost of all activities plus the cost of consumable material was summed up to get the final cost for each type of CT scan. The practical (used) capacity of personnel was deducted from the annual capacity to know the unused capacity of personnel. The practical capacity or utilisation time of CT equipment is deducted from annual capacity or the annual utilisation time. The cost of unused capacity of personnel and the cost of unutilised capacity or idle time cost of CT scan was calculated. All calculations were done via Microsoft Excel 2007. 


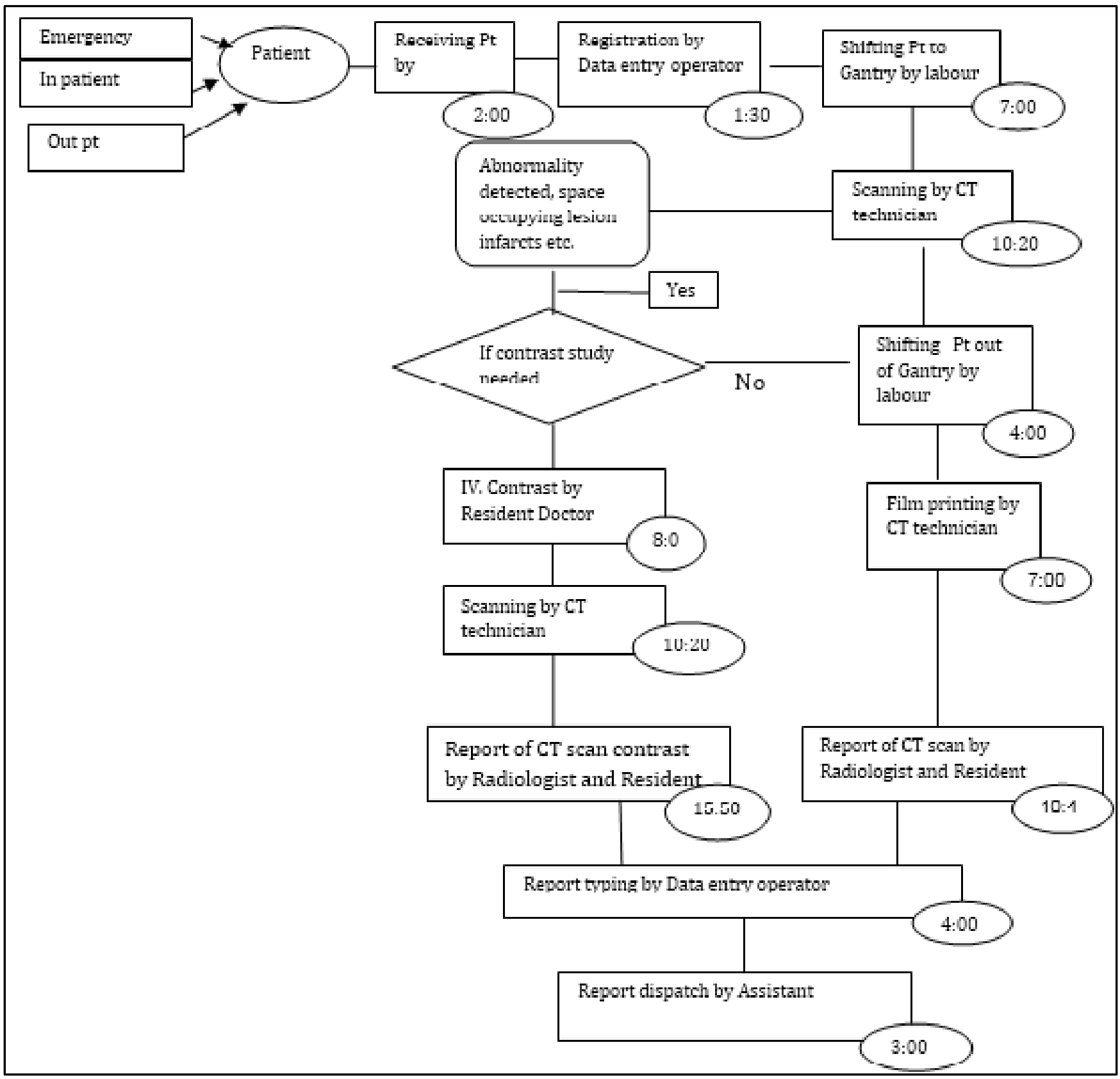

Figure 1. Process Map of Computed Tomography Scanning Brain Plain and Contrast Studies. Each Box denotes One Activity with Personnel and the Time (Minutes: Seconds) required for each Activity. Time shown in the Bottom Circle.

\section{RESULTS}

Activities of CT scan procedure is illustrated in Process map and shown in Figure 1.

\section{Costs Estimation}

All costs of CT scan were estimated by applying TDABC. Activity cost pool, cost drivers, half year expenses, expenses per hour and a minute were shown in Table 1.

\section{Staff Costs}

The practical capacity (time) for the radiologist (R) was 828 hours or 49680 minutes (M), and the gross salary (expenses of hospital) was Rs. 490590/half year, and Rs. 9.88 per minute. Similarly, the senior resident's (SR) estimated cost was Rs. $4.83 / \mathrm{m}$. The average reporting time for CT brain plain was 10:40 minutes and seconds (m:s), results of the reporting cost was Rs. 156.90 (R; Rs. 105.39 plus SR; Rs. 51.51). The resident doctor's mean time for a contrast procedure was 8 minutes. The cost was Rs. 38.64 for each contrast procedure. The cost of CT brain contrast reporting was Rs. 271.50 (activity time= 15:50 m:s, cost Rs. 156.43/ radiologist $+76.47 / \mathrm{SR}+38.64 / \mathrm{SR})$. Similarly reporting costs for CT abdomen scan were estimated and shown in Table 2. 


\begin{tabular}{|c|c|c|c|c|c|}
\hline Sl. No. & Activity Cost Pool & Cost Driver & Half Year & Expenses Indian Rupees & Capacity Cost Rate \\
\hline 1 & Reporting & $\begin{array}{l}\text { Radiologist } \\
\text { Man Hours }\end{array}$ & 490590 & $592.50 / \mathrm{Hr}$ & $9.88 / \min$ \\
\hline 2 & Reporting IV contrast & $\begin{array}{l}\text { Resident Dr. } \\
\text { Man Hours }\end{array}$ & 240000 & $289.86 / \mathrm{Hr}$ & $4.83 / \mathrm{min}$ \\
\hline 3 & Scanning printing & $\begin{array}{l}\text { CT. Technician } \\
\text { Man Hours }\end{array}$ & 72000 & $86.96 / \mathrm{Hr}$ & $1.45 / \mathrm{min}$ \\
\hline 4 & Registration typing report & $\begin{array}{c}\text { Assistant/ DEO Man } \\
\text { Hours }\end{array}$ & 60000 & $72.47 / \mathrm{Hr}$ & $1.20 / \mathrm{min}$ \\
\hline 5 & Shifting patient & Labour Hours & 52500 & $63.41 / \mathrm{Hr}$ & $1.06 / \mathrm{min}$ \\
\hline 6 & Material & Scan Film Units & 478175.20 & 146.25 & $146.25 / \mathrm{min}$ \\
\hline 7 & IV contrast & Units & 360000 & 2400/Bottle & $600 /$ scan $1200 /$ scan \\
\hline 8 & Equipment depreciation & Machine Hours & 448000 & $541.06 / \mathrm{Hr}$ & $9.01 / \mathrm{min}$ \\
\hline 9 & Equipment AMC & Machine Hours & 575000 & $694.45 / \mathrm{Hr}$ & $11.58 / \mathrm{min}$ \\
\hline 10 & Equipment energy cost & Machine Hours & 798720 & $964.64 / \mathrm{Hr}$ & $16.07 / \mathrm{min}$ \\
\hline 11 & Building rental cost & Machine Hours & 231000 & $278.98 / \mathrm{Hr}$ & $4.65 / \mathrm{min}$ \\
\hline 12 & Support equipment & Machine Hours & 11461.5 & $13.84 / \mathrm{Hr}$ & $0.23 / \mathrm{min}$ \\
\hline 13 & Furniture & Machine Hours & 81080.1 & $97.92 / \mathrm{Hr}$ & $1.63 / \mathrm{min}$ \\
\hline 14 & Support equip. energy AC & Machine Hours & 552000 & $500 / \mathrm{Hr}$ & $8.33 / \mathrm{min}$ \\
\hline 15 & Energy, light & Machine Hours & 105984 & $96 / \mathrm{Hr}$ & $1.60 / \mathrm{min}$ \\
\hline 16 & Indirect consumables & Units & 36945 & $44.62 / \mathrm{Hr}$ & $0.74 / \mathrm{min}$ \\
\hline 17 & Build. maintenance & Machine Hours & 43041.6 & $51.98 / \mathrm{Hr}$ & $0.87 / \mathrm{min}$ \\
\hline 18 & Housekeeping & Machine Hours & 120984 & $146.11 / \mathrm{Hr}$ & $2.43 / \mathrm{min}$ \\
\hline 19 & Linen & Number of Units & 9720 & $11.74 / \mathrm{Hr}$ & $0.19 / \mathrm{min}$ \\
\hline 20 & Laundry & Number of Units & 12000 & $14.19 / \mathrm{Hr}$ & $0.24 / \mathrm{min}$ \\
\hline 21 & Communication & Machine Hours & 3600 & $14.50 / \mathrm{Hr}$ & $0.24 / \mathrm{min}$ \\
\hline 22 & Property tax & Machine Hours & 106337.98 & $128.42 / \mathrm{Hr}$ & $2.14 / \mathrm{min}$ \\
\hline 23 & Administration & Man Hours & 124208.50 & $150 / \mathrm{Hr}$ & $30.68 / \min$ \\
\hline
\end{tabular}

The Half Year Capacity of Theoretical Time (HYCTT) for doctors was 66240 minutes (138 days $\times 8$ hours $\times 60$ ) and the practical time estimated was $49680 \mathrm{M}(138$ days $\times 6$ hours $\times 60)$. The unused capacity of doctors was $16560 \mathrm{M}$ and the calculated cost of unused capacity of the radiologist was Rs. 654451.20 and for resident doctor it was Rs. 79984.80 . 


\begin{tabular}{|c|c|c|c|c|c|c|c|c|c|c|c|}
\hline $\begin{array}{l}\frac{0}{0} \\
\frac{\pi}{3} \\
\frac{\pi}{\pi} \\
\frac{\pi}{0} \\
0\end{array}$ & 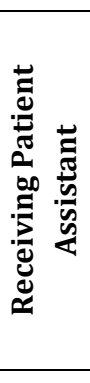 & 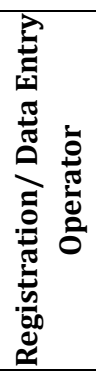 & 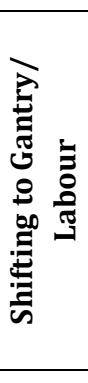 & 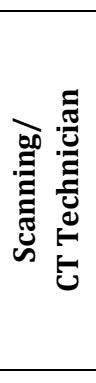 & 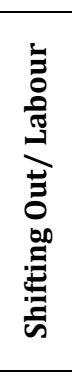 & 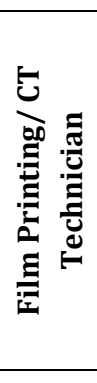 & 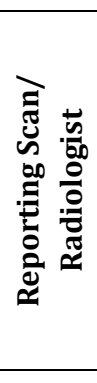 & 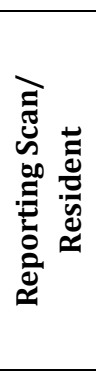 & 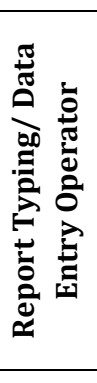 & 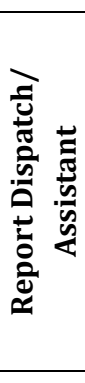 & 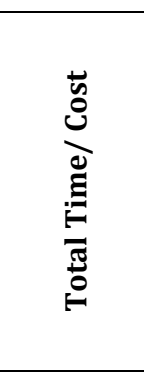 \\
\hline \multirow[t]{2}{*}{ Brain } & $2: 00$ & $1: 30$ & 7 & $10: 20$ & $4: 00$ & 7:00 & $10: 40$ & $10: 40$ & 4:00 & $3: 00$ & 49:30 \\
\hline & 2.4 & 1.8 & 7.42 & 15 & 4.24 & 10.15 & 105.4 & 51.51 & 4.8 & 3.6 & Rs.206.29 \\
\hline \multirow[t]{2}{*}{ Brain Cont* } & $2: 00$ & $1: 30$ & 7 & $14: 40$ & $4: 00$ & $10: 20$ & $15: 50$ & $15: 50$ & 4:00 & $3: 00$ & $70: 20$ \\
\hline & 2.4 & 1.8 & 7.42 & 21.3 & 4.24 & 14.98 & 156.4 & 76.47 & 4.8 & 3.6 & Rs.332.17 \\
\hline \multirow[t]{2}{*}{ Abdomen } & $2: 00$ & $1: 30$ & 7 & $10: 54$ & $4: 00$ & $10: 00$ & $15: 50$ & $15: 50$ & 4:00 & $3: 00$ & $58: 14$ \\
\hline & 2.4 & 1.8 & 7.42 & 15.8 & 4.24 & 14.5 & 156.4 & 76.47 & 4.8 & 3.6 & Rs.287.46 \\
\hline \multirow[t]{2}{*}{ Abd. Cont* } & $2: 00$ & $1: 30$ & 7 & $16: 40$ & $4: 00$ & $15: 20$ & $17: 00$ & $17: 00$ & 4:00 & $3: 00$ & 78:30 \\
\hline & 2.4 & 1.8 & 7.42 & 24.2 & 4.24 & 22.23 & 168 & 82.11 & 4.8 & 3.6 & Rs.359.37 \\
\hline
\end{tabular}

*Resident doctor's time for IV contrast was 8 minutes and cost was Rs. 38.64 added to contrast studies.

\section{CT Technician Cost and other Human Resources Costs}

The CT technician's HY gross salary was Rs. 72000, and the cost was Rs. 1.45/ minute. The CT technician mean time for CT brain plain was 10:20 m:s and cost was Rs. 14.98 and for printing film was Rs. 10.15 (7:00 m:s), CT brain contrast was Rs. 21.26 (14:40 m:s), and printing was Rs. 14.98 (10:20 m:s). Similarly for other activities like receiving the patient by assistant the cost was Rs. 2.40 (2:00 m:s), registration by data

entry operator (DEO) cost was Rs. 1.80 (1:30 m:s), shifting the patient to gantry by unskilled labour cost was Rs. 7.42 (7:00 m:s) and shifting the patient out of gantry to waiting area cost was Rs. 4.24 (4:00 m:s), typing the report by DEO cost was Rs. 4.80 (4:00 m:s), finally dispatching the report by the assistant cost was Rs. 3.60 (3:00 m:s). The total time consumed by all activities of CT scan brain plain was 49:30 m:s and the cost incurred was Rs. 206.29 and for CT scan brain contrast the time was 70:20 m:s and cost was Rs. 332.17. The cost of human resources for CT abdomen scan were shown in Table 2.

The Half Year Capacity of the Theoretical Time (HYCTT) of the CT technician was 66240 minutes (M), (138 days $\times 8$ hours $\times 60)$ and the practical time estimated was $49680 \mathrm{M}$ (138 days $\times 6$ hours $\times 60$ ). The unused capacity of CT technician was $16560 \mathrm{M}$ and the calculated cost was Rs. $24012(16560 \times 1.45)$, and for three CT technicians' unused capacity cost was Rs. 72036 .

\section{Equipment Cost}

The purchase cost of CT scan was Rs. 99.57 lakhs, minimum residual value here was set at Rs. 9.957 lakhs as per the straight line diminishing balance method and it was Rs. 8.96 lakhs. The annual cost over 10 year's amortisation was Rs. 8.96 lakhs and results Rs. 4.48 lakhs for study period (184 days), and the cost is divided by $49680 \mathrm{M}$ of personnel and Rs. 9.01/minute (rounded to Rs. 9.00). The rent of CT scan area (notional estimate) was Rs. 231000 for six months, and the cost is divided by $49680 \mathrm{M}$. The estimated cost was Rs. $4.65 /$ minute. The half-year maintenance cost of the equipment was Rs. 575000 and the estimated cost was Rs.

$11.58 /$ minute. The electricity consumed by the CT scanner was 416 units per day ( $52 \mathrm{KWH} \times 8$ hours $\times$ Rs. $12 /$ Unit) and worked for 160 days in study period, the cost was Rs. 964.64/hour and Rs. 16.07/minute. The cost of machine hours includes rental charges, machine expenses (depreciation, repairs and annual maintenance) and power consumed during working hours. The CT Scanner Machine Hours' cost was determined for a minute and it was Rs. 41.30 (notional rent per minute $4.65+$ depreciation of CT scanner per minute $9.00+$ annual maintenance per minute $11.58+$ electricity consumed by CT scanner per minute charges 16.07). The time duration for CT scan brain was 10:20 m:s and cost was Rs. 426.76. The time duration for CT brain contrast was 14:40 m:s and the cost was Rs. 605.73. Similarly, the machine hour cost of CT abdomen was estimated and shown in Table 3.

\begin{tabular}{|c|c|c|c|}
\hline $\begin{array}{c}\text { Sl. } \\
\text { No. }\end{array}$ & $\begin{array}{c}\text { Cost } \\
\text { Variable }\end{array}$ & $\begin{array}{c}\text { Scanning } \\
\text { Time }\end{array}$ & $\begin{array}{c}\text { Cost of Machine } \\
\text { Hours }\end{array}$ \\
\hline 1 & Brain Plain & $10: 20 \mathrm{Min}$ & Rs. 426.76 \\
\hline 2 & $\begin{array}{c}\text { Brain } \\
\text { Contrast }\end{array}$ & $14: 40 \mathrm{Min}$ & Rs. 605.73 \\
\hline 3 & $\begin{array}{c}\text { Abdomen } \\
\text { Plain }\end{array}$ & $10: 54 \mathrm{Min}$ & Rs. 450.17 \\
\hline 4 & $\begin{array}{c}\text { Abd. } \\
\text { Contrast }\end{array}$ & $16: 40 \mathrm{Min}$ & Rs. 688.33 \\
\hline \multicolumn{4}{|c|}{ Table 3. Machine Hour Cost of CT Scanning Procedures } \\
\hline
\end{tabular}


The Half-Year Capacity of the Theoretical Time (HYCTT) of the CT equipment was 170880 minutes (178 days $\times 16$ hours $\times 60$ ) and the practical time (utilised time) estimated was $49680 \mathrm{M}(138$ days $\times 6$ hours $\times 60)$. The idle time was $121200 \mathrm{M}$ and the calculated cost of idle time for the CT scanner was Rs. 50,05,560 (Rs. 41.30 per minute).

\section{Material Cost}

The material cost of CT brain was Rs. 146.25 for brain contrast in addition to above cost, the additional film cost was Rs. 138.79 and cost of contrast was Rs. 600. Similarly, material cost for CT abdomen scan was estimated and shown in Table 4.

\begin{tabular}{|c|c|c|c|c|c|c|c|c|c|c|}
\hline Sl. No. & $\begin{array}{c}\text { Cost } \\
\text { Variable }\end{array}$ & $\begin{array}{c}\text { Film } \\
\text { Cost }\end{array}$ & $\begin{array}{c}\text { Cover } \\
\text { Cost }\end{array}$ & $\begin{array}{c}\text { Report and } \\
\text { Indents }\end{array}$ & Ink Jet & $\begin{array}{c}\text { Register } \\
\text { and Indent }\end{array}$ & $\begin{array}{c}\text { Film } \\
\text { Contrast }\end{array}$ & $\begin{array}{c}\text { IV } \\
\text { Contrast }\end{array}$ & $\begin{array}{c}\text { Oral } \\
\text { Contrast }\end{array}$ & Total Cost \\
\hline 1 & Brain Plain & 138.79 & 6.4 & 0.28 & 0.4 & 0.38 & & & 146.25 \\
\hline 2 & Brain Contrast & 138.79 & 6.4 & 0.28 & 0.4 & 0.38 & 138.8 & 600 & & 885.04 \\
\hline 3 & Abdomen Plain & 138.79 & 6.4 & 0.28 & 0.4 & 0.38 & & & 146.25 \\
\hline 4 & Abd. Contrast & 138.79 & 6.4 & 0.28 & 0.4 & 0.38 & 138.8 & 1200 & 225 & 1710.04 \\
\hline \multicolumn{8}{|c|}{ Table 4. Material Cost of CT Procedures } \\
\hline
\end{tabular}

\section{Overhead Cost}

The cost of auxiliary equipment was Rs. 254700, the estimated depreciation was Rs. 22923/year. For the study period, it was Rs. 11461.50 and Rs. $0.23 /$ minute. The cost of furniture was Rs. 180178. The estimated depreciation per year was Rs. 162160.2 and for the study period was Rs. $81080 /$ half year, Rs. $1.63 /$ minute. The 10 tons AC consumed 10 units/hour and worked for 24 hours in a day.
The estimated cost was Rs. 3000/day and Rs. $8.33 /$ minute. The other electrical equipments and lighting consumed $6 \mathrm{KWH}$ for 8 hours a day and the consumed energy was 48 units/day, the estimated cost was Rs. 96/hour taking consideration of 6 hours' work time of CT scanner, consumption of other equipment cost Rs. 1.6/minute. All other overheads calculated for CT scan brain and abdomen. The overhead costs were shown in Table 5.

\begin{tabular}{|c|c|c|c|c|c|c|c|c|c|c|c|}
\hline $\begin{array}{c}\text { Cost } \\
\text { Variable }\end{array}$ & $\begin{array}{c}\text { Support } \\
\text { Equipment }\end{array}$ & Furniture & $\begin{array}{c}\text { Energy } \\
\text { AC and } \\
\text { Others }\end{array}$ & Consumables & $\begin{array}{c}\text { Building } \\
\text { Maintenance }\end{array}$ & $\begin{array}{c}\text { House } \\
\text { keep }\end{array}$ & Linen & Laundry & IT & Property & Administration \\
\hline $\mathrm{Br}$ & 2.37 & 16.84 & 102.6 & 7.65 & 8.99 & 25.1 & 1.96 & 2.48 & 0.24 & 22.02 & 25.84 \\
\hline $\mathrm{Br} \mathrm{C}$ & 3.37 & 23.9 & 145.63 & 10.9 & 12.76 & 35.64 & 2.79 & 3.52 & 0.35 & 31.39 & 36.67 \\
\hline $\mathrm{Ab}$ & 2.5 & 17.76 & 108.24 & 8.06 & 9.48 & 26.49 & 2.07 & 2.62 & 0.26 & 23.33 & 27.25 \\
\hline $\mathrm{Ab} \mathrm{C}$ & 3.83 & 27.16 & 165.49 & 12.3 & 14.5 & 40.5 & 3.17 & 4 & 0.4 & 35.67 & 41.67 \\
\hline \multicolumn{8}{|c|}{ Table 5. Overhead Costs of CT Procedures } \\
\hline
\end{tabular}

$\mathrm{Br}=$ Brain; $\mathrm{Br} \mathrm{C}=$ Brain contrast $\mathrm{Ab}=$ Abdomen; $\mathrm{Ab} \mathrm{C}=$ Abdomen contrast.

*Energy cost of $\mathrm{AC}$ and others are summed together.

With the above results the following costs were calculated for CT brain, the direct labour cost (DLC) was Rs. 206.29 (20.73\% of total costs), the machine hours cost (MHC) was Rs. 426.76 (42.87\%), and the material cost (DMC) was Rs. 146.25 (14.69\%), the batch level (BLC) which includes costs of auxiliary equipment, furniture, energy consumption and indirect material expenses was Rs. 129.46 (13.01\%). The sustaining level cost (SLC) which includes costs of building maintenance, housekeeping, linen, laundry and information technology expenses was Rs. 38.77 (3.89\%). The facility level cost (FLC) which includes property tax and the indirect labour apportioned to CT unit was Rs. 47.86 (4.81\%). The costs and percentages of CT brain are shown in Figure 2. For the brain contrast DLC: Rs. 332.17 (15.44\%); MHC: Rs. 605.73 (28.15\%); DMC: Rs. 885.04 (41.13\%); BLC was Rs. 205.75 (9.56\%); SLC: Rs. 55.06 (2.56\%); and FLC: Rs. 68.06 (3.16\%). The costs and percentages of CT brain contrast are shown in Figure 3.

With the above results, the estimated costs of CT scan activities were summed up to obtain total cost for each procedure. The CT brain cost was Rs. 995.39 and CT brain contrast was Rs. 2151.81. Similarly, cost of CT abdomen scan was Rs. 1106.8 and abdomen contrast was Rs. 3120.62. They are shown in Table 6.

\begin{tabular}{|c|c|c|c|c|c|c|c|c|}
\hline $\begin{array}{c}\text { Sl. } \\
\text { No. }\end{array}$ & $\begin{array}{c}\text { Cost } \\
\text { Variable }\end{array}$ & $\begin{array}{c}\text { Direct } \\
\text { Material }\end{array}$ & $\begin{array}{c}\text { Direct } \\
\text { Labour }\end{array}$ & $\begin{array}{c}\text { Machine Hour } \\
\text { Cost }\end{array}$ & $\begin{array}{c}\text { Batch Level } \\
\text { Cost }\end{array}$ & $\begin{array}{c}\text { Sustaining Level } \\
\text { Cost }\end{array}$ & $\begin{array}{c}\text { Facility Level } \\
\text { Cost }\end{array}$ & $\begin{array}{c}\text { Total } \\
\text { Cost }\end{array}$ \\
\hline 1 & Brain & 146.25 & 206.29 & 426.76 & 129.46 & 38.77 & 47.86 & 995.39 \\
\hline & & $14.69 \%$ & $20.73 \%$ & $42.87 \%$ & $13.01 \%$ & $3.89 \%$ & $4.81 \%$ & \\
\hline 2 & Brain Cont. & 885.04 & 332.17 & 605.73 & 205.75 & 55.06 & 68.06 & 2151.81 \\
\hline & & $41.13 \%$ & $15.44 \%$ & $28.15 \%$ & $9.56 \%$ & $2.56 \%$ & $3.16 \%$ & \\
\hline 3 & Abdomen & 146.25 & 287.46 & 450.17 & 136.56 & 40.92 & 45.44 & 1106.8 \\
\hline & & $13.21 \%$ & $25.97 \%$ & $40.67 \%$ & $12.34 \%$ & $3.70 \%$ & $4.11 \%$ & \\
\hline 4 & Abd. Cont.** & 1710.04 & 359.37 & 688.33 & 230.81 & 62.57 & 69.5 & 3120.62 \\
\hline \multicolumn{7}{|c|}{} \\
\hline
\end{tabular}

\footnotetext{
**Abdomen contrast
} 


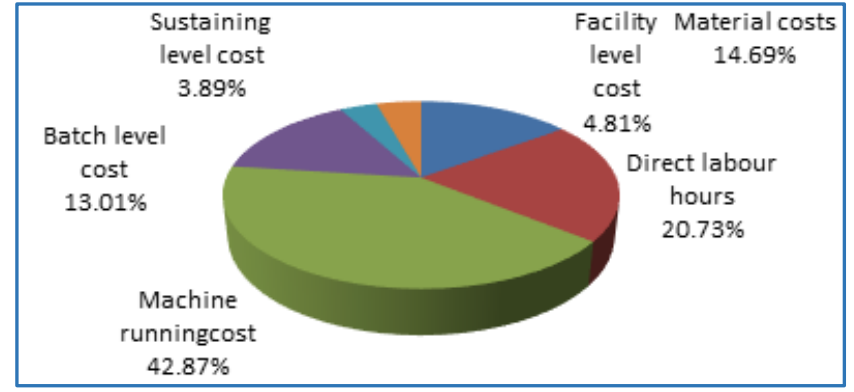

Figure 2. Brain Plain Costs

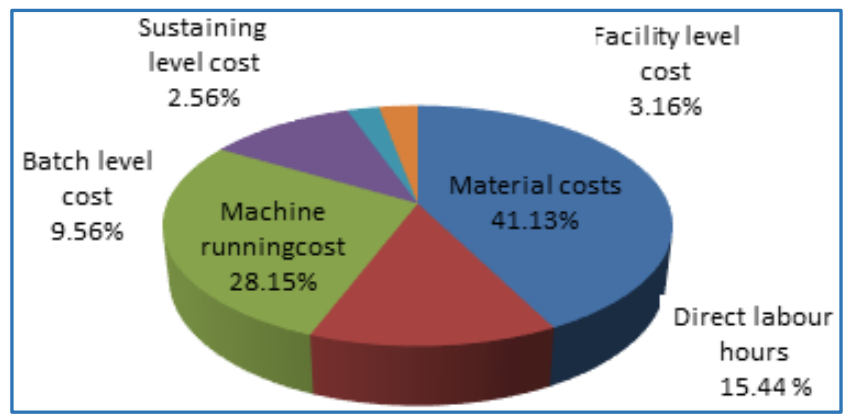

Figure 3. Brain Contrast Costs

\section{DISCUSSION}

In health care delivery, the cost analysis is an important issue due to increasing patient's demands versus scarce resources.[21] When resources are limited, the efficiency is required to maximise the capacity of resources. TDABC estimates the costs and time required for all activities and provides valuable information for process improvement and also cost containment.[15,22] Cost drivers are important, because they reveal the scope for improvement. This model can be updated easily and if any changes in capacity or costs may be adjusted to calculate a new capacity cost rate.[23] The public hospitals are moving towards the value-based and third party assessor's payments. After assessing the medical service to specific patients, there is a need to understand and analyse true costs for specific services. The granularity on utilised costs can be obtained by this method.[8] This study demonstrates how TDABC can be applied to measure actual cost of resources in CT scanning. This study has several strengths. This is a reliable method to estimate real costs of services. By this method we identified unused capacity and cost of personnel; idle time and cost of CT equipment.

According to our results the machine hour cost (42.87\%) comprised of the highest share for the CT brain investigation and other costs are in descending order; direct labour cost (20.73\%), direct material cost $(14.69 \%)$, batch level cost (13.01\%), facility level cost (4.81\%) and sustaining level cost (3.89\%). For CT brain contrast the direct material cost $(41.13 \%)$ comprised of the highest share and other costs in descending order, machine hour cost (28.15\%), direct labour cost $(15.44 \%)$, batch level cost $(9.56 \%)$, facility level cost (3.16\%) and sustaining level cost (2.56\%). Rajabi and Dabiri (2012) in a similar study reported the share of manpower cost was higher (50\%) than material cost $(22 \%)$ and equipment depreciation (13\%) and other centres allocation $(15 \%) \cdot{ }^{[17]}$
Laurila and Suramo et al (2000) stated that when switching from the conventional costing methods to new methods all types of costs rose, except there was a drop in overhead costs from $57 \%$ to $16 \%$. Because the modern tools are giving accurate methods of calculating overhead costs,[24] we found similar results in our study.

In their study by Lorusso and Quaia et al (2015), they reported that the mean radiologist time was 19.7 minutes and personnel cost was $31 \%$ on cost analysis CT contrast in diagnosis of focal liver lesions.[25] Our study findings of CT brain contrast was matching with the above study.

Our study suggests that the TDABC methodology has major impact in identifying the process improvement, resources allocation which will be helpful in decision making. By knowing costs, the efficiency can be improved by reduction of costs and optimum utilisation of resources. It can be applied to various services in the hospital and hence proven to be a reliable method to estimate real costs.[15,16]

\section{Limitations}

In this study, the main limitation was energy cost calculation. The energy consumption calculation requires technical person who knows the power utilization modes of medical equipments. Power measurement device with computer recording is required for accuracy. CT scanner was off mode during night ( 8 - 10) hours; the energy consumption is lower at the starting time and booting mode.

\section{Ethical Considerations}

Ethical issues (including consent, misconduct, data fabrication and/or falsification, double publication and/or submission, redundancy, plagiarism, etc.) have been completely taken care of by the author.

\section{CONCLUSION}

Calculation of costs for CT scanning was based on capacity rate, unit level, batch level, sustaining level and facility level, costs of unused capacity of personnel and idle time of equipment are the important conclusions of this research. The TDABC methodology will be a pathway in continuous and incremental improvement of service delivery. The cost identification is more precise than any traditional costing methods, which will help to evaluate the performance of a service.

The following suggestions can be made from the study conducted: The CT scan service should be used genuinely because of its cost. To utilize the idle time of CT scanner, the hospital provider may appoint more CT technicians. The evaluation of performance for service delivery shall be undertaken in each department such that the service provider can make out whether the department is in the path of improvement or not and incremental improvement of service will increase its efficiency and effectiveness.

\section{ACKNOWLEDGEMENT}

The author wishes to thank all the team of Radiology Department in the hospital. 


\section{REFERENCES}

[1] Kumar PN, Sharma S. Break-Even analysis of CT Scan facility at a multi-specialty hospital. International Journal of Scientific Research 2014;3(4):330-2. http://www.worldwidejournals.org/internationaljournal-of-scintific-research-(IJSR)/articles.pdf 2017.

[2] Muchantef K, Forman HP. Cost accounting in radiology: the practice of radiology. Perspective cost accounting in radiology: new directions and importance for policy. American Journal of Roentgentology 2005;185(6):1404-7.

http://www.ajronline.org/doi/abs/10.2214/AJR.05.0 495 Access 2 Jan, 2017.

[3] Atif MD, Sulaiman SAS, Shafie AA, et al. Determination of chest x-ray cost using activity based costing approach at Penang general hospital, Malaysia. Pan African Medical Journal 2012;12:40.

http://ia902604.us.archive.org/16/items/pubmedPMC3415060/PMC3415060-PAMJ-12-40.pdf Access 25 Jan, 2017.

[4] Michela A, Irvine L. Activity based costing in healthcare: a UK case study. Research in Healthcare Financial Management 2005;10(1):61-75.

http://www.gefin.net.br/upload/arquivos/15086288 5b680fdbe42dc6aa7ecf4ade.pdf

[5] Carine E, Maja S, Valdete S. Activity based costing: is it applicable in an event organizing firm? Bachelor thesis Management Accounting. Jönköping university: 2007.

http://www.diva-portal.org/smash/get/diva2: 4461/ fulltext01 Access 4 April, 2017.

[6] Horngren CT, Datar SM, Foster G. Activity-based costing and activity-based Management. In: Horngren CT, Datar SM, Foster G, eds. Cost Accounting: a managerial emphasis. $11^{\text {th }}$ edn. India: Pearson Education Asia 2003.

[7] Ashford CC. Activity-based costing system in the service sector: a strategic approach for enhancing managerial decision making and competitiveness. International Journal of Business and Management. 2011;6(11):3-10.

URL: http://dx.doi.org/10.5539/ijbm.v6n11p3.

[8] Akhavan S, Ward L, Bozic KJ. Time-driven activitybased costing more accurately reflects costs in arthroplasty surgery. In the Proceedings of 2015 Knee Society Symposium. Clinical Orthopaedic Related Research 2016;474(1):8-15.

http://dx.doi.org/10.1007/s11999-015-4214-0

Access 16 April, 2017.

[9] Hoozée S, Hansen SC. A comparison of activity-based costing and time-driven activity-based costing. Faculty and researcher publications collection. Calhoun Institutional Archives of the Naval Postgraduate School 2014:1-58.

http://hdl.handle.net/10945/47751

[10] Demeere N, Stouthuysen K, Roodhooft F. Time-driven activity-based costing in an outpatient clinic environment: development, relevance and managerial impact. Health Policy 2009;92(2-3):296-304.

j.healthpol.2009.05.003 Access 16 April, 2017.
[11] Namazi MD. Time-driven activity-based costing: theory, applications and limitations. Iranian Journal of Management Studies 2016;9(3):457-82. http://ijms.ut.ac.ir/ Access 2 May,2017.

[12] Basuki B, Riediansyaf MD. The application of timedriven activity based costing in the hospitality industry: an exploratory case study. JAMAR 2014;12(1):27-35.

https://www.cmawebline.org/ontarget/wp-content/ uploads/2014/06/JAMARv12.1-TDABC-in-

Hospitality-Industry.pdf Access 2 May, 2017.

[13] Kaplan RS, Witkowski M, Abbott M, et al. Using time driven activity based costing to identify value improvement opportunities in healthcare. Journal of Health Care Management 2014;59(6):399-412.

http://journals.www.com/jhmonline/Abstract/2014/ 1.1000/UsingTimeDrivenActvityBasedCosting to.5.aspx Access 4 May, 2017.

[14] Öker F, Özyapici H. A new costing model in hospital management: time-driven activity-based costing system. The Health Care Manager (Frederick) 2013;32(1):23-36.

http://journals.lww.com/healthcaremanagerjournal/ Abstract/2013/01000/A_New_Costing_Model_in_Hos pital_Management_4.aspx Access 27 April, 2017.

[15] Anzai Y, Heilbrun ME, Haas D, et al. Dissecting costs of CT study: application of TDABC (Time-driven activitybased costing) in a tertiary academic center. Academic Radioligy 2017;24(2):200-8.

http://www.academicradiology.org/article/S10766332(16)30343-9/fulltext http://dx.doi.org/10.1016/j.acra.2016.11.001 Access 12 April, 2017.

[16] Hada MS, Chakravarty A, Mukherjee P. Activity based costing of diagnostic procedures at a nuclear medicine center of a tertiary care hospital. Indian Journal of Nuclear Medicine 2014;29(4):241-5.

http://www.ijnm.in/temp/IndianJNuclMed2942412902795_080347.pdf Access 12 April, 2017

[17] Rajabai A, Dabiri A. Applying activity based costing(ABC) method to calculate cost price in hospital and remedy services. Iranian Journal of Public Health 2012;41(4):100-7.

https://www.ncbi.nlm.nih.gov/pmc/articles/PMC348 1619/

[18] Özyürek H, Dinç Y. Time-driven activity based costing. International Journal of Business and Management Studies 2014;6(1):97-117.

[19] Erhun F, Mistry B, Platchek T, et al. Time driven activity-based costing of multi-vessel coronary artery bypass grafting across national boundaries to identify improvement opportunities: study protocol. British Medical Journal Open 2015;5(8): e008765.

http://bmjopen.bmj.com/content/bmjopen/5/8/e00 8765.ful.pdf Access 27 April, 2017. 
[20] Balakrishnan K, Goico B, Arjmand EM. Applying cost accounting to operating room staffing in Otolarygology: time-driven activity-based costing and outpatient adenotonsillectomy. Otolaryngology Head and Neck Surgery 2015;152(4):684-90.

http://journals.sagepub.com/doi/pdf/10.1177/0194 599814568273 access 5 May, 2017.

[21] Saini S, Sharma R, Levine LA, et al. Technical cost of CT examination. Radiology 2001;218(1):172-5.

http://pubs.rsna.org/doi/full/10.1148/radiology.218 1.r01ja0117 Access11Dec, 2016.

[22] Mandigo M, O'Neill K, Mistry B, et al. A time-driven activity-based costing model to improve health-care resources use in Mirebalais, Haiti. The Lancet 2015;385(Suppl 2):S22.

www.Thelancet.com Access April 30, 2017.
[23] Barndt RJ, Oehlers PF, Soltis GS. Time-driven activitybased costing. Today's CPA 2015:25-9. https://www.tscpa.org/docslibrary/activitybasedcost model_marapril2015.pdf April 30, 2017.

[24] Laurila J, Suramo I, Brommels M, et al. Activity-based costing in radiology. Application in a pediatric radiological unit. Acta Radiologica 2000;41(2):189-95. http://www.tandfonline.com/doi/pdf/10.1080/0284 18500127345037 Access 2 May 2017.

[25] Lorusso A, Quaia E, Poillucci G, et al. Activity-based cost analysis of contrast enhanced ultrasonography related to the diagnostic impact in focal liver lesion characterisation. Insights Imaging 2015;6(4):499-508. 